\title{
The male gonad of the marine nematode Enoplus: No single distal tip cell but multiple uniform epithelial cells
}

\author{
V.V. Yushin ${ }^{1,2}$, A.G. Afanasiev-Grigoriev ${ }^{1}$, V.V. Malakhov²,3 \\ ${ }^{I}$ A.V. Zhirmunsky Institute of Marine Biology FEB RAS, Palchevskogo Str., 17, Vladivostok 690041, \\ Russia.E-mail:vvyushin@yandex.ru (corresponding author) \\ ${ }^{2}$ Far Eastern Federal University, Vladivostok, 690600, Russia. \\ ${ }^{3}$ Department of Invertebrate Zoology, Biological Faculty, M.V. Lomonosov Moscow State Univer- \\ sity, Leninskie Gory, Moscow, 119991, Russia.
}

\begin{abstract}
The distal tip cell (DTC) is a large single cell located at the apex of nematode gonadal arms. It is well investigated in Caenorhabditis elegans Maupas, 1900 and described in many other species of class Chromadorea. It has been obtained convincing evidence that in C. elegans the DTC plays an essential role in the development of the gonads and regulation of gametogenesis. We have studied the fine structure of the distal part of the testis in free living marine nematodes Enoplus. TEM observations revealed the absence of a large specialized DTC at the apex of testes in E. michaelseni (Linstow, 1896) and E. brevis Bastian, 1865. The testis of both species is lined with numerous uniform testis epithelial cells (TEC) forming an uninterrupted epithelium adjacent to the basal lamina. Besides that, TEC form long outgrowths protruding deeply into the testis between spermatogonia. Unlike a single DTC of C. elegans, the multiple TEC in Enoplus spp. show hardly any signs of synthetic activity. They possess neither nucleoli nor a rough endoplasmic reticulum in their cytoplasm, but contain thick bundles of filaments giving no evidence for a glandular or a hormonal function. The multicellular epithelium of the distal part of the testis in Enoplus spp. complements other plesiomorphic characters of enoplid structure and development (e.g. indeterminate early development, absence of cell constancy, regeneration ability, preservation of the nuclear envelope in spermatozoa) and may be considered as additional evidence for the basal position of the order Enoplida within the phylum Nematoda.

How to cite this article: Yushin V.V., Afanasiev-Grigoriev A.G., Malakhov V.V. 2014. The male gonad of the marine nematode Enoplus: No single distal tip cell but multiple uniform epithelial cells // Invert. Zool. Vol.11. No.2. P.361-372.
\end{abstract}

KEY WORDS: Caenorhabditis elegans, distal tip cell, DTC, Enoplida, Enoplus brevis, Enoplus michaelseni, free-living marine nematodes, gametogenesis, testis.

\section{В мужских гонадах морских нематод рода Enoplus вместо единственной дистальной концевой клетки обнаружен многоклеточный эпителий}

\author{
В.В. Юшин ${ }^{1,2}$, А.Г. Афранасьев-Григорьев ${ }^{1}$, В.В. Малахов ${ }^{2,3}$ \\ ${ }^{1}$ Институт биологии моря имени А.В. Жирмунского ДВО РАН, ул. Пальчевского, 17, \\ Владивосток 690041, Россия. E-mail: vvyushin@yandex.ru \\ ${ }^{2}$ Дальневосточный федеральный университет, Владивосток 690600, Россия.
}


${ }^{3}$ Кафедра зоологии беспозвоночных, Биологический факультет Московсткого государственного университета им. М.В. Ломоносова, Ленинские Горы, Москва 119991, Россия.

РЕЗЮМЕ: Дистальная концевая клетка (Distal tip cell, DTC) - крупная одиночная клетка, расположенная на вершине половой трубки нематод. DTC хорошо исследованы у Caenorhabditis elegans Maupas, 1900 и некоторых других видов класса Chromadorea и считаются типичными для всех нематод. Мы изучили тонкое строение дистальной части семенника у представителей отряда Enoplida, свободноживущих морских нематод Enoplus. Электронно-микроскопические исследования показывают, что специализированной DTС на вершине семенника Enoplus michaelseni (Linstow, 1896) и E. brevis Bastian, 1865 нет. Дистальная часть семенника одета многочисленными одинаковыми клетками эпителия семенника (КЭС), формирующими непрерывный эпителий, прилегающий к базальной пластинке. Кроме того, КЭС формируют длинные отростки, проникающие между сперматогониями. В отличие от DTC $C$. elegans, многочисленные КЭС у Enoplus spp. синтетически инертны, в их ядрах нет развитых ядрышек, а в цитоплазме - шероховатого эндоплазматического ретикулюма. Предполагается, что в отличие от одиночной DTC C. elegans, многочисленные КЭС у Enoplus spp. функционируют скорее как опорные, нежели железистые или гормональные. Наличие многоклеточного эпителия в дистальной части семенника Enoplus spp. коррелирует с другими плезиоморфными чертами строения и развития эноплид, например, недетерминированным развитием, отсутствием постоянства клеточного состава, способностью к регенерации, сохранением ядерной оболочки в сперматозоидах, что подчеркивает базальное положение отряда Enoplida в системе типа Nematoda.

Как цитировать эту статью: Yushin V.V., Afanasiev-Grigoriev A.G., Malakhov V.V., 2014. The male gonad of the marine nematode Enoplus: No single distal tip cell but multiple uniform epithelial cells // Invert. Zool. Vol.11. No.2. P.361-372.

КЛЮЧЕВЫЕ СЛОВА: гаметогенез, свободноживущие морские нематоды, семенник, Caenorhabditis elegans, distal tip cell, DTC, Enoplida, Enoplus brevis, Enoplus michaelseni.

\section{Introduction}

The specialized distal tip cells (DTC) are large single cells positioned at the very distal tip of each arm of the nematode gonads as an integral part of the gonadal somatic epithelium (Chitwood, Chitwood, 1977; Foor, 1983; McKinnon, 1987; Wood, 1988; Bird, Bird, 1991; Wright, 1991; Lints, Hall, 2004). The DTC is an essential component keeping germline stem cells (GSC) in the so-called germline stem cell niche (Kimble, White, 1981; Hubbard 2007; Kimble, Crittenden, 2007; Kimble, 2011; Spradling et al., 2011; Hansen, Schedl, 2013). Cell lineage studies in Caenorhabditis elegans Maupas, 1900 and several other nematodes showed two primordial germ cells (Z2 and Z3) associated with two somatic precursors (Z1 and Z4) forming the gonad primordium (Sulston et al., 1997; Felix, 1999). During morphogenesis $Z 1$ and $Z 4$ give rise to two DTC each controlling gonadal arm elongation during development and the mitosis/ meiosis decision of the GSC, both during development and in the adult (Ehrenstein, Schierenberg, 1980; Lints, Hall, 2004; Kimble, Crittenden, 2007). Whether a germ cell self-renews or enters meiotic prophase is determined by its proximity to the DTC. In C. elegans males and hermaphrodites the DTC is a single cell which tightly wraps around the germ cells (Hall et al., 
1999). Proximal to the uniform GSC predominantly germ cells in the early stages of meiotic prophase I (leptotene, zygotene) are found indicating the beginning of the transition zone (Hall et al., 1999; Hansen et al., 2004; Kimble, Crittenden, 2007; Kimble, 2011).

The morphology and function of GSC niche formed by a single DTC has been studied in detail in C. elegans (Hall et al., 1999; Lints, Hall, 2004; Kimble, Crittenden, 2007; Hansen, Schedl, 2013), there are also data on DTC in another nematodes from the same order Rhabditida sensu De Ley and Blaxter, 2002 (Foor, 1983; Rudel et al., 2005) and for a free-living marine nematode of the order Chromadorida (Zograf, 2010). The order Enoplida, which includes free-living aquatic forms, is taxon within the phylum Nematoda showing some ancestral peculiarities correlating well with the putative basal position of the order Enoplida (Maggenti, 1963, 1981; Platonova, 1976; Malakhov, 1994, 1998; Voronov, Panchin, 1998; Yushin, Malakhov, 2004). Therefore, detailed data on the structure of the enoplid reproductive system including germ cell structure and development are of particular interest.

The absence of a morphologically distinct DTC in male and female gonads of two Enoplus species was mentioned earlier in papers containing data on the ultrastucture of the gonad epithelium (Yushin, Malakhov, 1997, 1998). This striking structural difference from the $C$. elegans gonad together with the great importance of the DTC for GSC niche formation and the control of mitosis/meiosis in GSC justifies a deeper analysis. For this purpose we initiated a detailed investigation of the testis distal tip in two other Enoplus species using transmission electron microscopy (TEM). The structure of GSC niche is compared to other more distant nematode taxa.

\section{Material and methods}

Adult males of Enoplus michaelseni (Linstow, 1896) De Man, 1904 (Enoplida, Enoplidae) were extracted from clusters of the bivalve mollusk Crenomytilus grayanus (Dunker, 1853) collected at the Marine Biological Station "Vostok" of the Institute of Marine Biology (Vostok Bay, Sea of Japan). Adult males of Enoplus brevis Bastian, 1865 were obtained from sand collected in the intertidal zone at White Sea Biological Station of Moscow State University (Kandalaksha Bay, White Sea). Live males of both species were cut transversely into two pieces each containing a distal testis regions.

The specimens were fixed for TEM at $4^{\circ} \mathrm{C}$ in $2.5 \%$ glutaraldehyde in $0.05 \mathrm{M}$ cacodylate buffer containing $21 \mathrm{mg} / \mathrm{ml} \mathrm{NaCl}$ and then postfixed in $2 \%$ osmium tetroxide in the same buffer containing $23 \mathrm{mg} / \mathrm{ml} \mathrm{NaCl}$. Postfixation was followed by en bloc staining for $2 \mathrm{~h}$ in $1 \%$ solution of uranyl acetate in distilled water and then the specimens were washed in distilled water and dehydrated in ethanol followed by isopropanol series and embedded in Epon $(E$. michaelseni) and Spurr (E. brevis) resin. Serial $0.7 \mu \mathrm{m}$ or $0.4 \mu \mathrm{m}$ thick sections stained with methylene blue and mounted in epoxyresin were studied and documented with a Leica DM2500B (Leica Microsystems) and a Biorevo BZ-9000 (Keyence, Japan) microscopes. Thin sections cut with a Leica UC6 ultratome and stained with lead citrate were examined with a Philips EM 300, JEOL JEM 100 S and Zeiss Libra 120 transmission electron microscopes. For low magnification panoramic views of sections scanning transmission electron microscopy (STEM) was used with a Zeiss Libra 120 electron microscope. The testes of two males of E. michaelseni and four males of $E$. brevis were examined for the present paper.

\section{Results}

The male reproductive system of Enoplus species consists of two opposite testes with dilated proximal parts (seminal vesicles) opening into a common vas deferens (Fig. 1A). Each testis is an epithelial tube filled with spermatogenous cells at successive stages of development. The very distal tip of a testis (germinal zone) contains spermatogonia. Following in distalproximal direction are zones of spermatocytes, spermatids, and immature spermatozoa filling a seminal vesicle (Fig. 1A). 


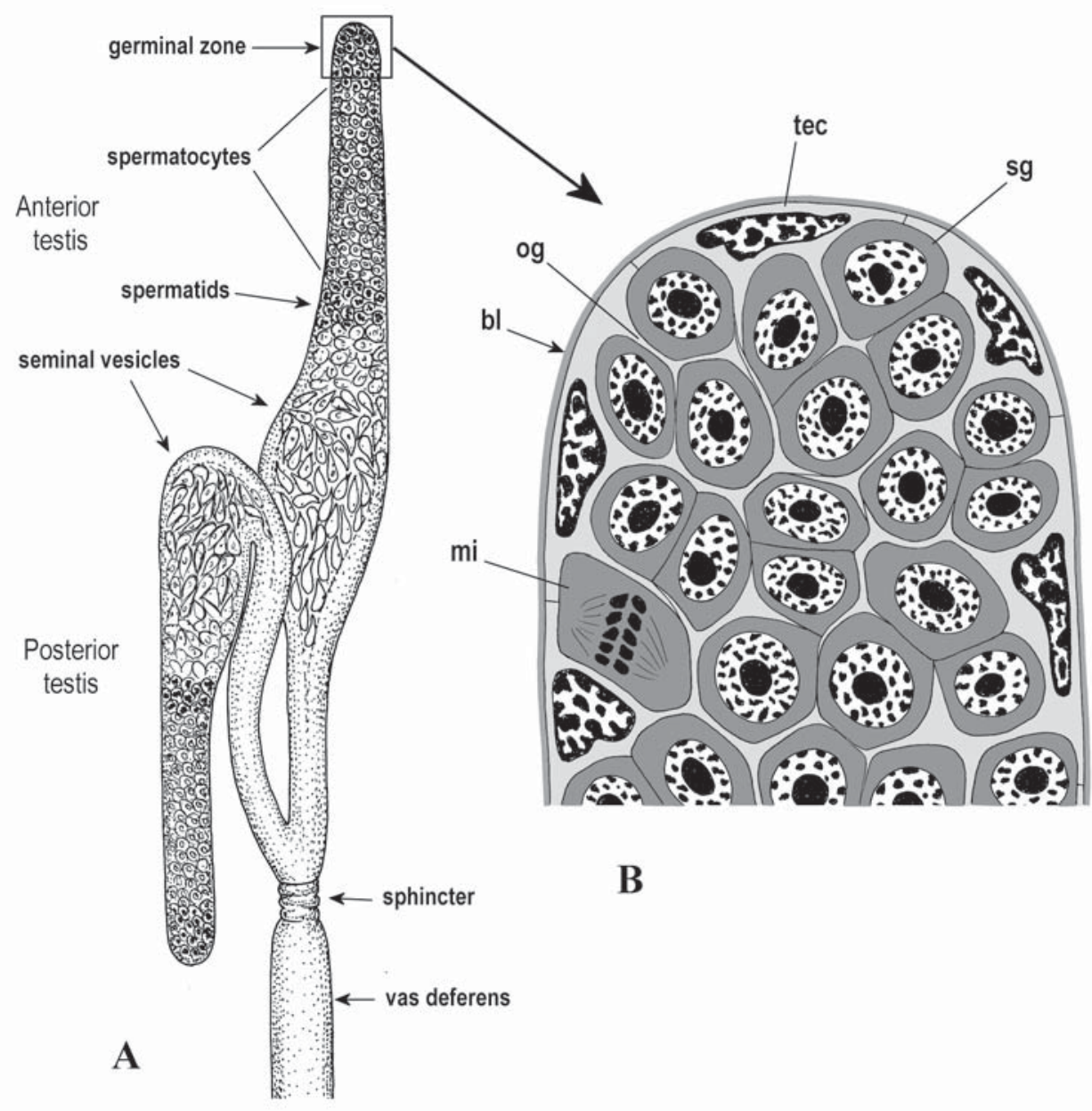

Fig. 1. Schematic representations of the male gonad in Enoplus species.

A - gross morphology of the mail gonadal tubes; B - distal tip of testis; reconstruction based on TEM observations. Abbreviations: $\mathrm{bl}$ - basal lamina; $\mathrm{mi}$ - mitotic cell; og — outgrowth of testis epithelial cell; $\mathrm{sg}$ - spermatogonium; tec - testis epithelial cell.

Рис. 1. Схема строения мужских гонад у видов рода Enoplus.

А - общий вид мужских половых трубок; В - дистальный конец семенника; реконструкция на основе наблюдений с помощью ТЕM. bl - базальная пластинка; $\mathrm{mi}$ - митотическая клетка; og - выросты эпителиальных клеток семенника; sg - сперматогоний; tес — эпителиальные клетки семенника.

The distal tip of the testis is a cylinder of 40 $50 \mu \mathrm{m}$ in diameter with a semispherical blind end (Figs. 1B, 2A-C, 3). Serial semithin sections in both species show the testis blind end as a cluster of germ cells delineated by a thin epithelium with no single somatic cell with the characteristics of a specialized DTC (Fig. 2AC). The closely packed germ cells (spermatogo- nia) are uniform in size and structure; the occasionally visible nuclei of the testis epithelium are easily recognized on semithin sections (Fig. 2C).

The testis is surrounded a by $75 \mathrm{~nm}$ thick basal lamina exposed to the body cavity (Figs. 4A, B, 5A). Internally the basal lamina adjoins the testis epithelial cells (TEC) with their lobated, triangle or flattened nuclei containing dense 

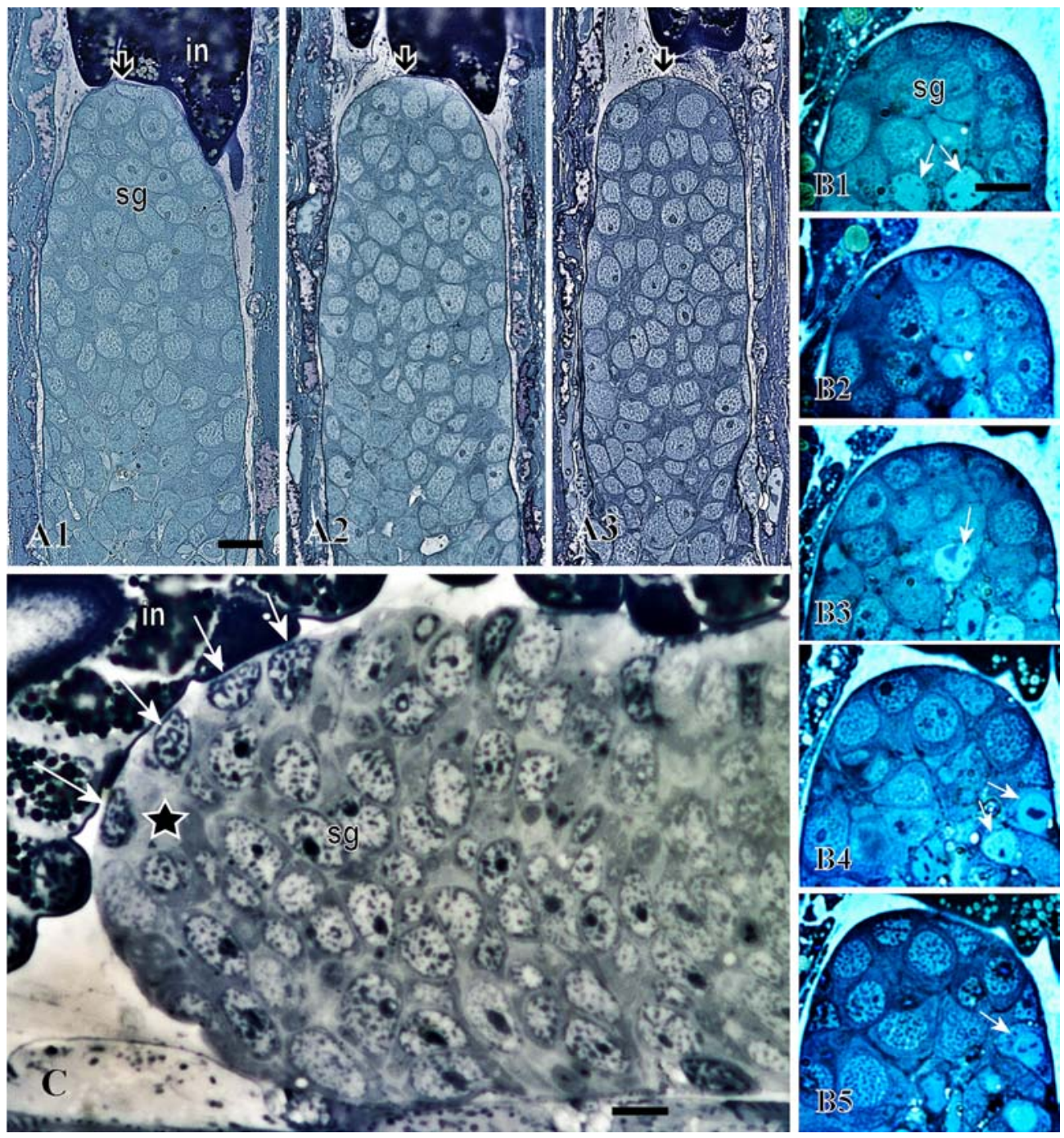

Fig. 2. The distal tip of the Enoplus spp. testis as seen on the longitudinal semi-thin sections with light microscopy. Note absence of a distal tip cell at the testis blind end (white bordered black arrows on A and asterisk on $\mathrm{C})$.

$\mathrm{A}-\mathrm{B}$ - Enoplus michaelseni, selection from serial semi-thin sections through the testes of two individuals; A1-A3 overview of the distal tip; $0.7 \mu \mathrm{m}$ thick sections with $5 \mu \mathrm{m}$ interval; B1-B5 - the very distal tip of the testis; $0.4 \mu \mathrm{m}$ thick sections with $2 \mu \mathrm{m}$ interval; white arrows show mitotic cells. C - Enoplus brevis; section through the distal tip showing nuclei of somatic epithelial cells (white arrows). Abbreviations: in - intestine; sg — spermatogonia. Scale bars: $\mathrm{A} 1-\mathrm{A} 3, \mathrm{~B} 1-\mathrm{B} 5-10 \mu \mathrm{m} ; \mathrm{C}-5 \mu \mathrm{m}$.

Рис. 2. Дистальный конец семенника Enoplus spp. на продольных полутонких срезах, световая микроскопия. У слепого конца семенника (отмечен черной стрелкой с белым ободком на А и звездочкой на С) нет дистальной концевой клетки.

A-B - Enoplus michaelseni, избранные полутонкие срезы из серийной резки семенников двух разных особей; A1-A3 - обзор дистального участка; срезы толщиной 0,7 мкм выбраны с интервалом 5 мкм; В1-В5 дистальный конец семенника; срезы толщиной 0,4 мкм выбраны с интервалом 2 мкм; белые стрелки указывают на митотические клетки. С - Enoplus brevis; срез дистального конца с хорошо заметными ядрами соматических эпителиальных клеток (белые стрелки). in - кишечник; sg - сперматогонии. Масштаб: A1-A3, B1-B5 - 10 мкм; С -5 мкм. 
clumps of chromatin (Figs. 2C, 3, 4A). The cytoplasm of the TEC is transparent and contains mitochondria, rare Golgi bodies, cisterns of rough endoplasmic reticulum (RER), ribosomes and bundles of filaments (Fig. 4A, B). Between the nucleus-containing cell bodies 0.1 $\mu \mathrm{m}$ thick flattened cytoplasmic outgrowths run along the basal lamina so that the spermatogonia are isolated from the basal lamina throughout the testis (Figs. 1B, 4A, B). Occasional dense clumps are detected under the TEC plasmalemma where it joins intimately the basal lamina (Fig. 5B, insert). Each clump is associated with a bundle of filaments and may be interpreted as epithelial hemidesmosomes.

At the very distal tip of the testis the TEC form long outgrowths protruding deeply into the testis in-between spermatogonia (Figs. 1B, 4A, B). The outgrowths squeezed between spermatogonia may be only $30 \mathrm{~nm}$ thick; the structures reminiscent of gap junctions are found occasionally in areas where TEC outgrowths contact spermatogonia (Fig. 4A, B, inserts). The dense bundles of filaments are typical for cytoplasm of TEC and their outgrowths (Fig. 4A, B). The spermatogonia found in the testis germinal zone are uniform polygonal cells of $9-11 \mu \mathrm{m}$ in size (Figs. 2, 3, 4A, B). The spherical or oval nucleus contains dense clumps of chromatin and a nucleolus; the thin layer of cytoplasm surrounding the nucleus contains clusters of mitochondria, free ribosomes, rare Golgi bodies, and cisterns of RER (Figs. 4A, B, 5A).

The testis germinal zone judged by the uniformity of germ cell nuclei and the occurrence of mitoses in both speciesis is roughly $100-150 \mu \mathrm{m}$ long. Here metaphase plates are found indicating mitotic proliferation of spermatogonia (Figs. 2B, $5 \mathrm{~A})$. Further away from the distal tip a switch to meiosis becomes evident in germ cells. An increase of components with synthetic function (RER, Golgi bodies, ribosomes) and the appearance of synthesis products (numerous vesicles with dense content) marks the stage of early primary spermatocytes (Fig. 5B). The TEC in the area of spermatocytes are flattened and each has a disc-shaped nucleus; the cells form no outgrowths into the testis cavity (Fig. 5B).

\section{Discussion}

The earlier observations on the female and male gonads of two Enoplus species (Yushin, Malakhov, 1997, 1998) and new data presented above demonstrate the absence of a morphologically differentiated cell comparable to the DTC in nematodes of the orders Rhabditida and Chromadorida, both from class Chromadorea sensu De Ley and Blaxter, 2002. In Enoplus spp., presenting the subclass Enoplea, the continuous epithelium at the distal tip of the testes and ovaries consists of multiple cells with no distinct differences in size and structure. The close morphological association of epithelial and germ cells in Enoplus testes is caused by long narrow extensions of epithelial cells penetrating between spermatogonia.

The multiple uniform cells of the distal tip epithelium in the Enoplus spp. are in line with many other structural and developmental plesiomorphic features of Enoplida nematodes including early indeterminate cleavage, late establishment of bilateral symmetry and late separation of the germ line(Malakhov, 1994; Voronov, Panchin 1998; Voronov, 1999; Felix, 2004; Joshi, Rothman, 2005). In enoplids no eutely (cell constancy) characteristic of rhabditids like C. elegans is found, and they are even capable of limited regeneration (Malakhov, 1994, 1998; Rusin, Malakhov, 1998). In contrast to all other studied nematodes the spermatozoa of enoplids possess a distinct nuclear envelope as a plesiomorphic character (Yushin, Malakhov, 2004, AfanasievGrigoriev, Yushin, 2009). The multiple epithelial cells in the distal tip region of the Enoplus spp gonad in contrast to the large single DTC of chromadorean species may be considered as one more argument for the basal position of the order Enoplida in the system of the phylum Nematoda. This position is confirmed also by latest molecular phylogenetic analyses of nematode relationships (van Megen et al., 2009; Bik et al., 2014; Blaxter, Koutsovoulos, 2014).

Important peculiarity in nature of gonadal epithelium is known for several parasitic orders of the class Enoplea: Dioctophymatida, Trichinellida, Marimermitida and Benthimermith- 


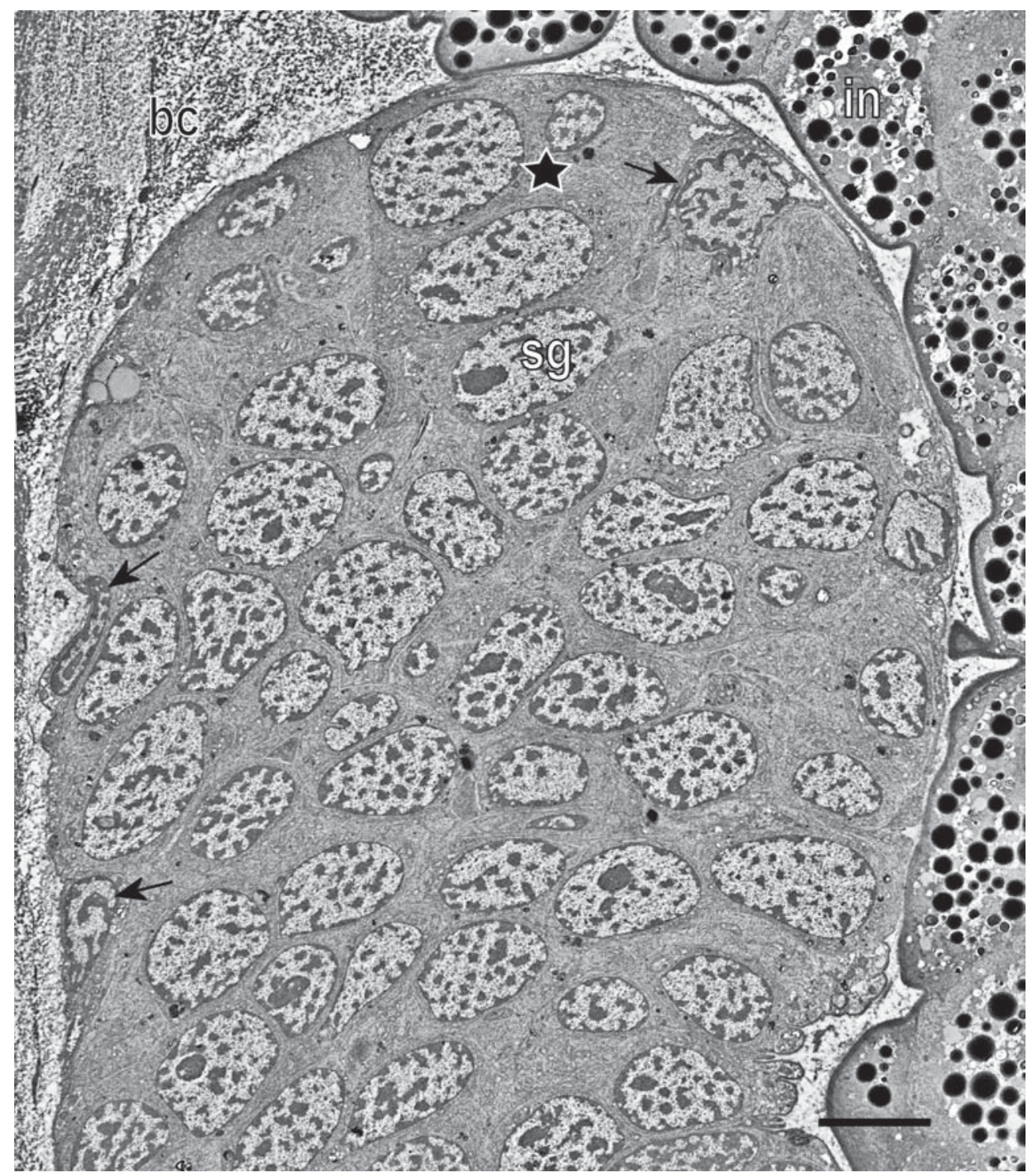

Fig. 3. Enoplus brevis, distal tip of the testis, longitudinal section, STEM. Asterisk marks testis blind end; black arrows show nuclei of testis epithelial cells.

Abbreviations: bc — body cavity; in — intestine; sg — spermatogonia. Scale bar: $5 \mu \mathrm{m}$.

Рис. 3. Enoplus brevis, дистальный конец семенника, продольный срез, STEM. Звездочкой отмечен слепой конец семенника; черные стрелки указывают на ядра эпителиальных клеток семенника. $\mathrm{bc}$ - полость тела; in — кишечник; sg — сперматогонии. Масштаб: 5 мкм.

ida (Foor, 1983a, b; Bird, Bird, 1991; Miljutin, 2014a, b). They have so called 'hologonic' gonads where GSC are proliferated from a series of germinal areas extending the length of the gonad unlike 'telogonic' gonads of chromadorean taxa and Enoplus where GSC prolifera- tion is confined to the distal end of the testis or ovary. In hologonic gonads development of germ cells is radial across the gonad and structure of GSC niche is obscure. The epithelial cells regulating mitosis/meiosis decision must be multiple and spreading along the gonad. 
DTC in the ovaries of the rhabditid nematodes C. elegans and Pristionchus pacificus Sommer, Carta, Kim et Sternberg, 1996 are relatively large cells with long, protruding processes running along the gonad periphery to envelope the spherical oogonia (Hall et al., 1999; Rudel et al., 2005). The processes are about 20-fold longer than the diameter of an oogonium (Crittenden et al., 1994; Rudel et al., 2005). The processes terminate at the point where the mitotic germinal zone changes over to the transition zone where cells start to enter meiosis (Rudel et al., 2005; Hansen, Schedl, 2013; Kim et al., 2013). Between processes of the DTC the gonadal wall is reduced to a basal lamina. The DTC also form short processes protruding between several most distally positioned germ cells (Kimble, Crittenden, 2007; Hansen, Schedl, 2013). No other epithelial cells are found in the mitotic region. Thus, the single DTC is the only somatic cell at the rhabditid gonad tip. The male gonads (testes) in dioecious species of nematodes possess a DTC as well as a potential GSC niche (Wright, 1991). The study in the free-living marine nematode Paracyatholaimus pugettensis Wieser et Hopper, 1967 (Chromadorida) shows distinct DTC in the germinal zone of the testis as a large elongated cell containing a nucleus with dispersed chromatin and a well developed nucleolus (Zograf, 2010). The DTC of P. pugettensis also forms long cytoplasmic outgrowths covering mitotically active GSC.

Ultrastructural data of the rhabditid and chromadorid DTC revealed their synthetic activity
(Foor, 1983; Rudel et al., 2005; Kimble, Crittenden, 2007; Zograf, 2010). They possess a nucleus with dispersed chromatin and a well developed nucleolus. The DTC cytoplasm contains ribosomes, cysterns of RER, Golgi bodies and vesicles. In the DTC of $P$. pacificus large transparent vesicles are concentrated in the cell periphery which contacts the basal lamina ( $\mathrm{Ru}-$ del et al., 2005). It was shown that in C. elegans the DTC controls the mitosis/meiosis decision in germ cells via Notch/LIN-12 signalling (Kimble, Crittenden, 2007; Kershner et al., 2013) keeping germ cells near the DTC in a mitotic state (Hansen et al., 2004).

In Enoplus the structure of epithelial cells at the distal tip of the testis gives no evidence for high metabolic activity. They rather look as if they had a structural rather than a glandular or hormonal function. At the same time, the consecutive events in the gonads of chromadorean nematodes and Enoplus spp. are comparable: the germinal zone of the GSC niche is followed by germ cells at successive stages of meiosis. In both cases the germinal zone contains a small cluster of cells which conserve mitotic activity (Hansen, Schedl, 2013; Kim et al., 2013). In C. elegans short DTC processes embrace the distalmost germ cells in the GSC niche (Kimble, Crittenden, 2007). It is surmised that these germ cells receive the strongest signal and that the short processes surrounding these germ cells anchor them within the niche (Hall et al. 1999). In Enoplus spp. the epithelial cells of the distal tip have characteristic outgrowths which run into the testis between spermatogonia (Fig. 1B).

Fig. 4. Enoplus michaelseni, distal tip of the testis, longitudinal sections, TEM.

A - epithelial cell with outgrowths (asterisks) protruding between spermatogonia; black arrowheads mark bundles of filaments. B - spermatogonia at the distal tip of the testis are closely associated with testis epithelial cells and their outgrowths (asterisks). Inserts in A and B (high magnification views of areas surrounded by dotted squares): contacts (black arrowheads) of spermatogonium and testis epithelium. Abbreviations: bc — body cavity; bl — basal lamina; mc - mitochondria; ne - nucleus of the testis epithelial cell; ns - nucleus of spermatogonium; nu — nucleolus. Scale bars: A, B $-2 \mu \mathrm{m}$; inserts $-0.5 \mu \mathrm{m}$.

Рис. 4. Enoplus michaelseni, дистальный конец семенника, продольный срез, ТЕМ.

А -эпителиальные клетки с отростками (звездочки) проникающими между сперматогониями; черные наконечники указывают на пучки волокон. В - у дистального конца семенника сперматогонии находятся в тесном контакте с эпителиальными клетками и их отростками (звездочки). Врезки на А и В (увеличенное изображение участков, отмеченных пунктирными прямоугольниками): контакты (черные наконечники) сперматогониев с эпителием семенника. bc - полость тела; bl - базальная пластинка; mс — митохондрии; nе — ядро эпителиальной клетки семенника; ns — ядро сперматогония; nu — ядрышко. Масштаб: A, B — 2 мкм; врезки - 0,5 мкм. 

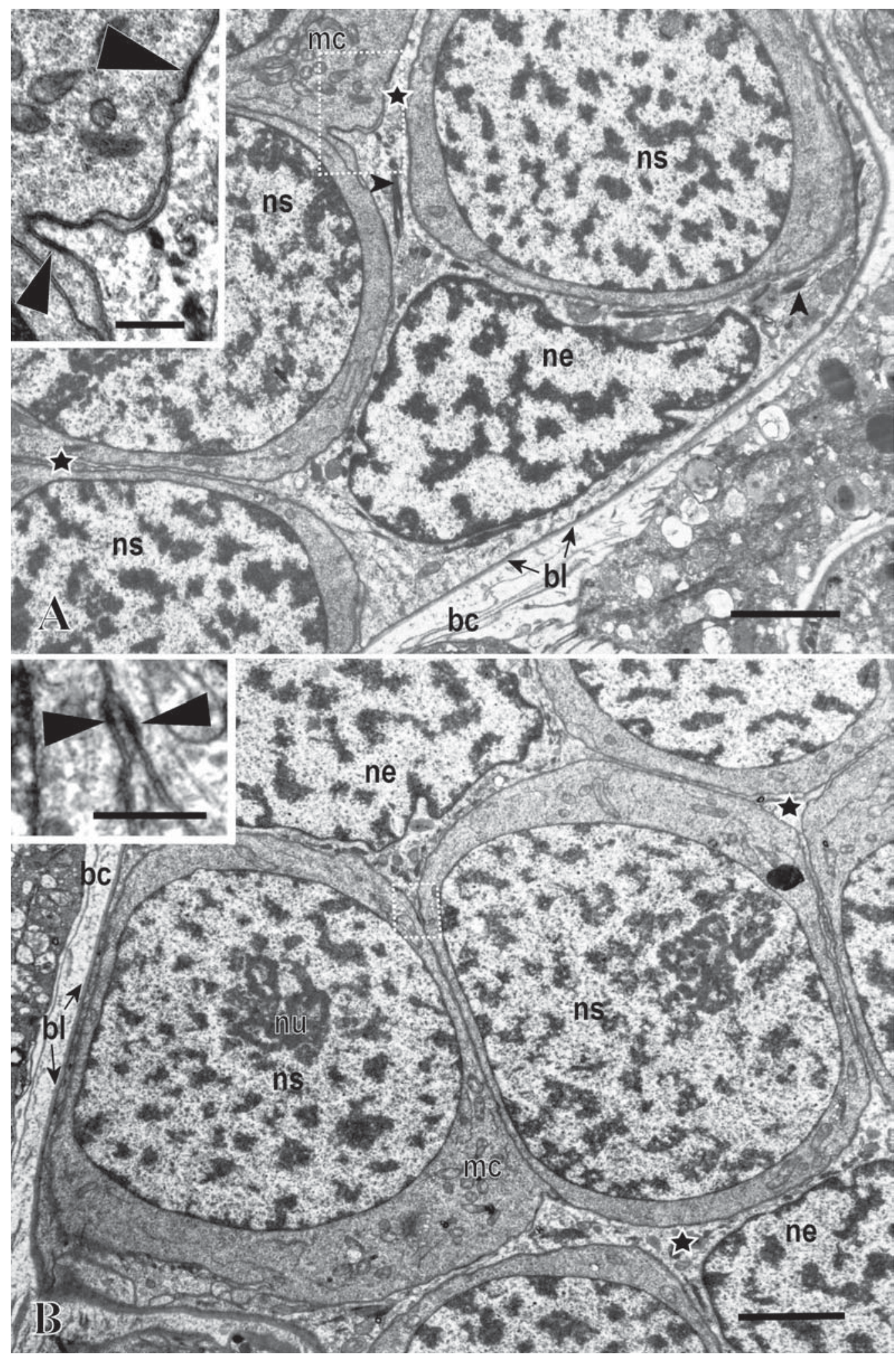


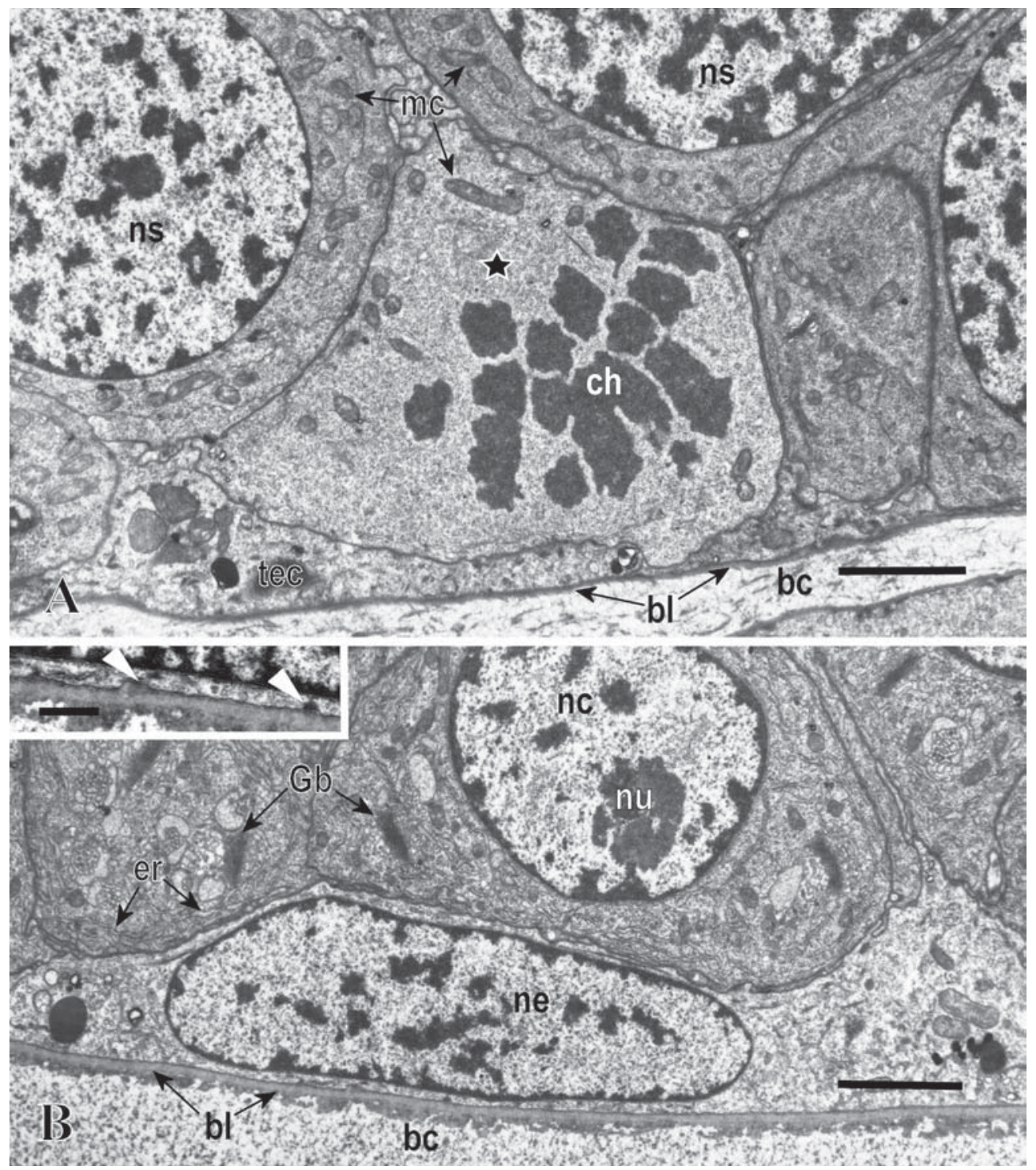

Fig. 5. Enoplus michaelseni testis, longitudinal sections, TEM.

A - germinal zone, the mitotic spermatogonium (asterisk) with chromosomes in mitotic metaphase . B - zone of early spermatocytes; insert - hemidesmosome-like structures (white arrowheads) joining the epithelial cell to basal lamina. Abbreviations: bc — body cavity; bl — basal lamina; ch — chromosomes; er — rough endoplasmic reticulum; Gb Golgi bodies; mc — mitochondria; nc — nucleus of spermatocyte; ne — nucleus of the testis epithelial cell; ns — nucleus of spermatogonium; nu — nucleolus; tec — testis epithelial cell. Scale bars: A, B - $2 \mu \mathrm{m}$; insert - $0.5 \mu \mathrm{m}$.

Рис. 5. Семенник Enoplus michaelseni, продольные срезы, ТЕМ.

А - герминальная зона, митотический сперматогоний (звездочка) с метафазными хромосомами. В - зона ранних сперматоцитов; врезка - полудесмосомы (белые наконечники), присоединяющие эпителиальные клетки к базальной пластинке. bc - полость тела; bl — базальная пластинка; ch — хромосомы; er шероховатый эндоплазматический ретикулюм; $\mathrm{Gb}$ - тельца Гольджи; mс — митохондрии; nc — ядро сперматоцита; ne - ядро эпителиальной клетки семенника; ns — ядро сперматогония; nu - ядрышко; tec - эпителиальной клетки семенника. Масштаб: А, В - 2 мкм; врезка - 0,5 мкм. 
While this morphological peculiarity of the TEC is compatible with a role in regulating germ cell differentiation, the absence of visible markers for a secreting function does not support this assumption.

However multiplicity and small size of TEC in Enoplus testes do not change general situation with germ cell mitosis/meiosis decision and arrangement of germ cells as successive stages along testis which is the same as in testes of the nematodes with actively functioning large DTC. From morphological point of view TEC must be considered as homologue to DTC and can provide male gonad with the same function. Hormonal activity of Enoplus TEC cannot be categorically omitted without molecular studies. Low physiological value of each individual TEC may be compensated by their multiplicity together with their close contacts with GSC. Taking this assumption in account we can hypothesize that single DTC of chromadorean nematodes may be evolved from primarily multicellular gonadal epithelium which may be illustrated by the multiple TEC of the distal tip of Enoplus testis. The evolution trend from undetermined multicellularity to highly determined eutely inevitably leads to reduction of cell number and concentration of cellular function in a few or even in a single cell.

\section{Acknowledgements}

The reported study was partially supported by the RF Government grant (research project \# 11.G34.31.0010), RFBR (\# 14-04-00334-a), FEB RAS (\# 12-III-A-06-098) and the Grass Foundation (1994). The authors are grateful to D.V. Fomin (Far East Center of Electron Microscopy, Institute of Marine Biology) for technical assistance and to A.O. Dennis Willows, Richard R. Strathmann and Scott Schwinge (Friday Harbor Laboratories of the University of Washington) for good research facilities in 1994.

\section{References}

Afanasiev-Grigoriev A.G., Yushin V.V. 2009. Electron microscopic study of spermiogenesis in the free-living marine nematode Leptosomatides marinae Pla- tonova 1976 (Enoplida: Leptosomatidae) // Russian Journal of Marine Biology. Vol.35. P.156-163.

Bik H.M., Lambshead P.J., Thomas W.K., Lunt D.H. 2010. Moving towards a complete molecular framework of the Nematoda: a focus on the Enoplida and early-branching clades // BMC Evolutionary Biology. Vol.10: 353. doi: 10.1186/1471-2148-10-353.

Bird A.F., Bird J. 1991. The Structure of Nematodes. San Diego: Academic Press. 316 p.

Blaxter M., Koutsovoulos G. 2014. The evolution of parasitism in Nematoda// Parasitology. DOI: 10.1017/ S0031182014000791

Chitwood B.G., Chitwood M.B. 1977. Introduction to Nematology. Baltimore, London, Tokyo: University Park Press. 334 p.

Crittenden S.L., Troemel E.R., Evans T.C., Kimble J. 1994. GLP-1 is localized to the mitotic region of the C. elegans germ line// Development. Vol.120. P.29012911.

De Ley P., Blaxter M.L. 2002. Systematic position and phylogeny // D. Lee (ed.). The Biology of Nematodes. London: Taylor \& Francis. P.1-30.

Ehrenstein G., Schierenberg E. 1980. Cell lineages and development of Caenorhabditis elegans and other nematodes // B.M. Zuckerman (ed.). Nematodes as Biological Models. Vol.1. London: Academic Press. P.1-71.

Félix M.-A. 1999. Evolution of developmental mechanisms in nematodes // Journal of Experimental Zoology. Part B: Molecular and Developmental Evolution. Vol.285. P.3-18

Félix M.-A. 2004. Developmental biology of nematodes what we learn from Caenorhabditis elegans // Z.X. Chen, S.Y. Chen, D.W. Dickson (eds.). Nematology advances and perspectives. Vol.1. Nematode morphology, physiology and ecology. Wallingford, UK: CABI Publishing. P.71-174.

Foor W.E. 1983a. Nematoda // K.G. Adiyodi, R.G. Adiyodi(eds). Reproductive Biology of Invertebrates. Vol.1. Oogenesis, Oviposition, and Oosorption. Chichester: John Wiley and Sons. P.223-256.

Foor W.E. 1983b. Nematoda // K.G. Adiyodi, R.G. Adiyodi (eds.). Reproductive Biology of Invertebrates. Vol.2. Spermatogenesis and Sperm Function. Chichester: John Wiley and Sons. P.221-256.

Hall D.H., Winfrey V.P., Blaeuer G., Hoffman L.H., Furuta T., Rose K.L., Hobert O., Greenstein D. 1999. Ultrastructural features of the adult hermaphrodite gonad of Caenorhabditis elegans: relations between the germ line and soma // Developmental Biology. Vol.212. P.101-123.

Hansen D., Hubbard E.J.A., Schedl T. 2004. Multi-pathway control of the proliferation versus meiotic development decision in the Caenorhabditis elegans germline // Developmental Biology. Vol.268. P.342-357.

Hansen D., Schedl T. 2013. Stem cell proliferation versus meiotic fate decision in Caenorhabditis elegans // $\mathrm{T}$. Schedl (ed.). Germ Cell Development in C. elegans. Advances in Experimental Medicine and Biology. Vol.757. New York, Heidelberg, Dordrecht, London: Springer. P.71-99.

Hubbard J.A. 2007. Caenorhabditis elegans germ line: a model for stem cell biology // Developmental Dynamics. Vol.236. P.3343-3357. 
Joshi P.M., Rothman J.H. 2005. Nematode gastrulation: having a blastocoel! // Current Biology. Vol.15. P.R495-R498.

Kershner A., Crittenden S.L., Friend K., Sorensen E.B., Porter D.F., Kimble J. 2013. Germline stem cells and their regulation in the nematode Caenorhabditis elegans // G. Hime, H. Abud (eds.). Transcriptional and Translational Regulation of Stem Cells. Advances in Experimental Medicine and Biology. Vol.786. P.29-46

Kim S., Spike C., Greenstein D. 2013. Control of oocyte growth and meiotic maturation in Caenorhabditis elegans // T. Schedl (ed.). Germ Cell Development in C. elegans. Advances in Experimental Medicine and Biology. Vol.757. New York, Heidelberg, Dordrecht, London: Springer. P.277-320.

Kimble J. 2011. Molecular regulation of the mitosis/ meiosis decision in multicellular organisms // Cold Spring Harbor Perspectives in Biology. 3: a002683.

Kimble J., Crittenden S.L. 2007. Controls of germline stem cells, entry into meiosis, and the sperm/oocyte decision in Caenorhabditis elegans // Annual Review of Cell and Developmental Biology. Vol.23. P.405-433.

Kimble J.E., White J.G. 1981 On the control of germ cell development in Caenorhabditis elegans // Developmental Biology.Vol.81. P.208-219.

Lints R., Hall D.H. 2004. Handbook of Worm Anatomy. The Reproductive System. http://www.wormatlas.org/ handbook/reproductivesystem/

MacKinnon B.M. 1987. A light and electron microscopical investigation of fertilization, chromosome behaviour, and early cleavage patterns in Heligmosomoides polygyrus (Nematoda: Trichostrongyloidea) // International Journal of Invertebrate Reproduction and Development. Vol.11. P.89-107.

Maggenti A.R. 1963. Comparative morphology in nemic phylogeny // E.C. Dougherty, Z.N. Brown, E.D. Hanson, W.D. Hartman (eds.). The Lower Metazoa. Berkeley, Los Angeles: University of California Press. P.273-282.

Maggenti A.R., 1981. General Nematology. New York, Heidelberg, Berlin: Springer. 384 p.

Malakhov V.V. 1994. Nematodes: Structure, Development, Classification, and Phylogeny. Washington, London: Smithsonian Institution Press. 286 p.

Malakhov V.V. 1998. Embryological and histological peculiarities of the order Enoplida, primitive group of nematodes // Russian Journal of Nematology. Vol. 6. P. 41-46.

Miljutin D.M. 2014a. Order Benthimermithida Tchesunov, 1995 // A. Schmidt-Rhaesa (ed.). Handbook of Zoology. Gastrotricha, Cycloneuralia and Gnathifera. Vol.2. Nematoda. Berlin/Boston: Walter de Gruyter GmbH. P.179-186.

Miljutin D.M. 2014b. Order Marimermithida Rubtzov 1980, emend. Tchesunov 1995 // A. Schmidt-Rhaesa (ed.). Handbook of Zoology. Gastrotricha, Cycloneuralia and Gnathifera. Vol.2. Nematoda. Berlin/Boston: Walter de Gruyter GmbH. P.345-350.

Platonova T.A. 1976. [The lower Enoplida (free-living marine nematodes) of the seas of the USSR] // O.A.
Skarlato (ed.). Nematody i ikh rol' v meiobentose [Nematodes and their role in meiobenthos]. Leningrad: Nauka. P.3-164 [in Russian].

Rudel D., Riebesell M., Sommer R.J. 2005. Gonadogenesis in Pristionchus pacificus and organ evolution: development, adult morphology and cell-cell interactions in the hermaphrodite gonad // Developmental Biology. Vol.277. P.200-221

Rusin L.Y., Malakhov V.V. 1998. Free-living nematodes possess no eutely // Doklady Biological Sciences. Vol.361. P.331-333.

Spradling A., Fuller M.T., Braun R.E., Yoshida S. 2011. Germline stem cells // Cold Spring Harbor Perspectives in Biology. 2011, 3: a002642.

Sulston J.E. 1997. Cell lineage // D.L. Riddle, T. Blumental, B.J. Meyer, J.R. Priess (eds.). C. elegans II. Cold Spring Harbor: Cold Spring Harbor Laboratory Press. P.123-155.

van Megen H., van den Elsen S., Holterman M., Karssen G., Mooyman P., Bongers T., Holovachov O., Bakker J. Helder J. 2009. A phylogenetic tree of nematodes based on about 1200 full-length small subunit ribosomal DNA sequences // Nematology. Vol.11. P.927-950.

Voronov D.A. 1999. The embryonic development of Pontonema vulgare (Enoplida: Oncholaimidae) with a discussion of nematode phylogeny // Russian Journal of Nematology. Vol.7. P.105-114.

Voronov D.A., Panchin Y.V. 1998. Cell lineage in marine nematode Enoplus brevis // Development. Vol.125. P.143-150.

Wood W.B. (ed.) 1988. The nematode Caenorhabditis elegans. New York: Cold Spring Harbor Laboratory. $667 \mathrm{p}$.

Wright K.A. 1991. Nematoda // F.W. Harrison, E.E. Ruppert (eds.). Microscopic Anatomy of Invertebrates. New York: Wiley-Liss. Vol.4. P.111-195.

Yushin V.V., Malakhov V.V. 1997. Ultrastructure of the female reproductive system in the free-living marine nematode Enoplus demani (Nematode: Enoplida) // Fundamental and Applied Nematology. Vol.20. P.115-125.

Yushin V.V., Malakhov V.V. 1998. Ultrastructure of sperm development in the free-living marine nematode Enoplus anisospiculus (Enoplida: Enoplidae) // Fundamental and Applied Nematology. Vol.21. P.213-225.

Yushin V.V., Malakhov V.V. 2004. Spermatogenesis and nematode phylogeny // R. Cook, D.J. Hunt (eds.). Nematology Monographs and Perspectives. Vol.2. Proceedings of the Fourth International Congress of Nematology, June 2002, Tenerife, Spain. Leiden, The Netherlands: Brill. P.655-665.

Zograf J.K. 2010. Ultrastructure of the male reproductive system of the free-living marine nematode Paracyatholaimus pugettensis Wieser \& Hopper, 1967 (Chromadorida: Cyatholaimidae) // Nematology. Vol.12. P.255-268.

Responsible editors: E.N. Temereva, K.G. Mikhailov 